Univerzitet u Beogradu
Poljoprivredni fakultet
Institut za poljoprivrednu tehniku
Naučni časopis
POLJOPRIVREDNA TEHNIKA
Godina XLV
Broj 1, 2020.
Strane: $10-19$

\title{
ASSESSMENT OF SOIL SATURATED HYDRAULIC CONDUCTIVITY AT VFSTR CAMPUS USING DRI METHOD
}

\author{
Aminul Islam* ${ }^{1}$, K.Ravi Chandra Charyulu ${ }^{1}$, Rami Reddy ${ }^{1}$ \\ Department of Applied Engineering, Vignan's Foundation for Science, \\ Technology and Research, Vadlamudi, 522213, India
}

\begin{abstract}
Study of soil hydraulc conductivity is the most important parameter for fluid flow and molecules transportation phenomena through the soil profile. The water reaches in the land surface in the form of precipitation and irrigation can flow over the ground, which eventually reaches in surface water body and flows through soil surface, contributes groundwater recharge. Estimation and evaluation of soil saturated hydraulic conductivity (Ks) are soil hydraulic properties that effect fluid flow ability through the soil medium which help to understand transmission properties and water balance in soils. The Green-Ampt (GA) model is best suited for infiltration on homogeneous, initially dry, rough and rough soils. The study is conducted to estimate steady state infiltration rate by using in-situ method named Double Ring Infiltrometer (DRI) and finding the spatial variation of infiltration rate and to estimate saturated hydraulic conductivity by using the Green-Ampt (G-A) model for 6 plots, having area $15 \mathrm{~m} \times 15 \mathrm{~m}$ each at Vadlamudi willage, Guntur district, Andhra Pradesh (India). The experiment conducted areas A1, A2, A6 is having more bulk density because of organic compounds in that area having comparatively less infiltration rate than A3, A4, A5. Point A1 having less moisture content with soil bulk density $1.95 \mathrm{~g} / \mathrm{cm}^{3}$ and having a maximum infiltration rate of $4.2 \mathrm{~cm} / \mathrm{h}$. The average estimated Ks was found $0.95 \mathrm{~cm} / \mathrm{h}$ from the experiment plot.
\end{abstract}

Keywords: Hydraulic conductivity, Infiltration rate, Precipitation, Green-Ampt $(G-A)$, Double Ring Infiltrometer (DRI)

\footnotetext{
${ }^{*}$ Corresponding Author. E-mail addres. aminul.ubkv@gmail.com
} 


\section{INTRODUCTION}

Infiltration is the important component of the hydrological cycle. Water gets into the surface of the earth in the form of precipitation and irrigation can flow over the ground, which ultimately reaches the currents, lakes, rivers and oceans or flows through the surface of the soil, contributing to the regeneration of water underground. Estimating and assessing the hydraulic conductivity (Ks) of saturated soil is the hydraulic properties of the soil that affect the capacity of the fluid flow through the soil, which helps to understand the characteristics of the transmission and the water balance in the soil. Infiltration is the water source to support the growth of vegetation. Infiltration is filtered from the soil, which eliminates many pollutants and complements groundwater supply in wells and waterways. However, water infiltration data for different soils are essential for understanding the drainage process, soil macro porosity controls discharge and infiltration processes (Das, 2014). Determination of infiltration quantitatively is also useful for understanding water availability and estimating the need for water for irrigation in crop production.

Precise methods are needed to characterize infiltration to develop better hydrological models (Islam et al., 2019). Equations and infiltration patterns are widely used in the design of irrigation, drainage and wastewater systems, exploring the characteristics of the effluent and the restoration of groundwater, modeling the flow of fluid with soil and pesticides from agricultural soils to designing the irrigation system.

Hydrological leakage and groundwater supply estimates, water infiltration data for different soils are essential for understanding the drainage process (Sihag et al., 2017). Infiltration modeling approaches are often divided into 3 different categories, such as physical, approximate, and empirical models. The physical approach requires the Richards solution, which describes the flow of water in the soil, taking into account soil conduction and soil pressure, which depends on the soil water content in certain boundary conditions. Simplified approaches include empirical models such as Kostiakov, Horton and Holtan, as well as models based on a physical foundation such as Green and Ampt and Philip. The empirical models are less constrained by the soil surface and soil profile hypotheses but are limited by the conditions for which they are calibrated because their parameters are determined based on the measured infiltration data in the field. Equations based on physical approximation use model parameters derived from water and soil properties and do not require in situ infiltration data (Fashi et al., 2016, Islam et al., 2017). Hydraulic conductivity is very important for the infiltration rate as it expresses the water flowing through the ground. Hydraulic control of unsaturated soil is a function of the pressure head and water distribution in the soil matrix. Soil saturated hydraulic conductivity $(\mathrm{Ks})$ is used as a parameter in many infiltration equations since it is easier to detect both unsaturated hydraulic conductivity and diffusion. In 1856, the French hydraulic engineer Darcy found that the special flow through the porous environment is directly proportional to the hydraulic gradient. The solution of the Richards equation requires many measurements to adequately describe changes in soil characteristics both vertically in the soil profile and at the point (Rooij, 2010), (Kostiakov,1932) and (Lewis, 1938) independently developed an empirical 
approach based on curve adaptation, adapting field data. Even Horton's approach has been criticized for not taking into account the importance of potential capillary slopes for reducing infiltration capacity and almost exclusively for controlling surface conditions (Bevin, 2004). The Philip's model is adapted to the constant rain intensity to determine the time of precipitation surplus and the resolution of the kinetic wave flow equation. These included storing depression between pond time and discharge time. In 1911, Green-Ampt (GA) developed a simple rough model that directly applies the Darcy Law. The initial infiltration equation was obtained on a surface covered with deeply homogeneous soil infiltration rate and find a spatial variation of infiltration rate and estimate saturated hydraulic conductivity using the Green-Ampt model.

\section{MATERIAL AND METHODOLOGY}

\section{Study Area}

The study area is located at Vignan's Foundation for Science, Technology and Research (VFSTR) campus, Vadlamudi, Guntur district, Andhra Pradesh $\left(16.2334^{\circ} \mathrm{N}\right.$, $\left.80.5509^{\circ} \mathrm{E}\right)$. The location has maximum and minimum temperature is $41^{\circ} \mathrm{C}$ and $27^{\circ} \mathrm{C}$ with average rainfall in the district is $830 \mathrm{~mm}$, experienced mostly by both south-west monsoon and the retreating monsoon.

The study area consists of a green house, we have taken 6 plots with the $15 \mathrm{~m} \times 15 \mathrm{~m}$ area and the infiltration test was conducted by using the DRI method at $10 \mathrm{~cm}$ depth from the surface with DRI method.

\section{Double Ring Infiltrometer (DRI)}

DRI consist of one metal cylindrical inner ring $30 \mathrm{~cm}$ diameter $29 \mathrm{~cm}$ height and outer ring $60 \mathrm{~cm}$ dia. Infiltration test has been conducted with the following steps.

Step 1: Cleared the sampling area of surface residues because it impedes to insert the ring when the surface was covered with vegetation.

Step 2: The cylinders were installed about $10 \mathrm{~cm}$ deep in the soil by taking care of the ring sides vertical and minimum soil disturbance.

Step 3: Measured the elevation difference with the help of sprit leveller.

Step 4: A polythene sheet was placed inside the inner ring and poured water to protect the soil surface from the disturbance.

Step 5: Add water inside the ring and the depth of water maintained up to depth 7-12 cm Step 6: Measured water level in the inner ring with the field type point gauge attached.

Step 7: Calculate steady state infiltration rate.

\section{Sample Collection}

At each site, six soil samples were collected and determined the initial water content, soil bulk density. 


\section{Moisture Percentage And Bulk Density Of Soil}

A gravimetric method was used to determine the initial water content of the soil. The wet specimens are weighed, dried in a hot air oven at $105^{\circ} \mathrm{C}$ for 24 hours, and then weighed again. The following equation used to determine water content.

$$
\theta_{\mathrm{m}}=\frac{\text { Mass wet soil }- \text { Mass dry soil }}{\text { Mass dry soil }}=\frac{\mathrm{m}_{\mathrm{w}}}{\mathrm{m}_{\mathrm{s}}}
$$

Volumetric soil water content (V) was obtained by using the equation with the length (L) and diameter (d) of the soil rings

Bulk density was of the soil

$$
V=\frac{\pi d^{2}}{4} L
$$

$$
\rho_{b}=\frac{\text { Mass of dry soil }\left(m_{s}\right)}{\text { The volume of soil }\left(V_{S}\right)}
$$

The volume of water content was then calculated by the equation:

$$
\frac{V_{w}}{V_{s}}=\frac{m_{w}}{m_{s}} x \frac{m_{s}}{V_{s}} x \frac{V_{w}}{m_{w}}
$$

Where,

$$
\begin{aligned}
& \mathbf{V}_{\mathbf{w}}=\operatorname{volume} \text { of water }\left(\mathrm{cm}^{3}\right) \\
& \mathbf{V}=\text { Dry soil volume }\left(\mathrm{cm}^{3}\right) \\
& \mathbf{\mathbf { m } _ { \mathbf { w } }}=\text { Mass of the water }(\mathbf{g}) \\
& \mathbf{m}_{\mathbf{s}}=\text { Mass of the dry soil }(\mathbf{g}) \\
& \qquad \theta_{i}=\theta_{m} \frac{\rho_{b}}{\rho_{w}}
\end{aligned}
$$

Where,

$$
\begin{aligned}
& \theta_{i}=\frac{V_{w}}{V_{s}}=\text { volumetric water content }\left(\mathrm{cm}^{3} \mathrm{~cm}^{-3}\right) \\
& \boldsymbol{\theta}_{\mathbf{m}}=\frac{\mathbf{m}_{\mathbf{w}}}{\mathbf{m}_{\mathbf{s}}}=\text { gravimetric water content }\left(\mathrm{gg}^{-1}\right), \\
& \boldsymbol{\rho}_{\mathbf{b}}=\frac{\mathbf{m}_{\mathbf{s}}}{\mathbf{V}_{\mathbf{s}}}=\text { bulk density of soil }\left(\mathbf{g c m}^{-3}\right) \\
& \boldsymbol{\rho}_{\mathbf{w}}=\frac{\mathbf{m}_{\mathbf{w}}}{\mathbf{V}_{\mathbf{w}}}=\text { density of water }\left(\mathbf{g ~ c m}^{-3}\right)
\end{aligned}
$$

\section{Estimation of Saturated Hydraulic Conductivity}

Saturated soil flow capacity is estimated using the DRI data Green-Ampt (GA) equation. DRI in situ data were used to generate data values $f$ (infiltration rate) and $F$ (cumulative infiltration) for different time values $(\mathrm{t})$. 
$\mathrm{F}$ values are displayed against $1 / \mathrm{F}$ in Excel and the most appropriate straight line is drawn through the drawn points. The intersection of the best fit line is saturated hydraulic conductivity (Ks) (Nimmo et al., 2009).

$$
f=\operatorname{Ks}\left(1+\frac{\eta S_{c}}{F}\right)
$$

Where,

$$
\begin{aligned}
& F=\text { Cumulative infiltration }(\mathrm{L}), \\
& \text { f= Infiltration capacity }(\mathrm{L} / \mathrm{T}), \\
& \eta=\text { Soil porosity, } \\
& \text { Sc= Capillary suction at the wetting front and } \\
& \text { Ks= Saturated hydraulic conductivity of the field (L/T) }
\end{aligned}
$$

Arrange the Green-Ampt equitation in the form of a line

$$
f=p+\frac{q}{F}
$$

Where,

$$
\begin{aligned}
& \mathrm{F}=\text { Cumulative infiltration }[\mathrm{L}] \\
& \mathrm{f}=\text { Infiltration capacity }[\mathrm{L} / \mathrm{T}] \\
& \mathrm{p} \text { and } \mathrm{q}=\text { Parameters of the infiltration model (Green-Ampt) }
\end{aligned}
$$

\section{RESULTS AND DISCUSSION}

The in-situ infiltration test was conducted in the field to find the spatial variability of infiltration rate. Based on the field tests at 6 plots at VFSTR campus, Vadlamudi, Guntur district, Andhra Pradesh and the results were analysed and individual infiltration curves have been produced. The in-situ infiltration rate reading was summarized in Fig. 1. The determined steady state infiltration rates for 6 plots were determined 4.2, 2.62, 2.72, $1.40,1.80,2.40 \mathrm{~cm} / \mathrm{h}$ respectively. The graph is drawn between infiltration rate, $\mathrm{cm} / \mathrm{h}$ and cumulative infiltration, 1/F. From the graph to plot A1, A2, A3, A4, A5, A6 the receptively intercept $(\mathrm{Ks})$ is $1.05,1.01,0.63,0.85,1.04,1.11(\mathrm{~cm} / \mathrm{h})$. The determined/estimated Ks rates and moisture contents and bulk density of the soil samples of different locations shown in Table 1. 


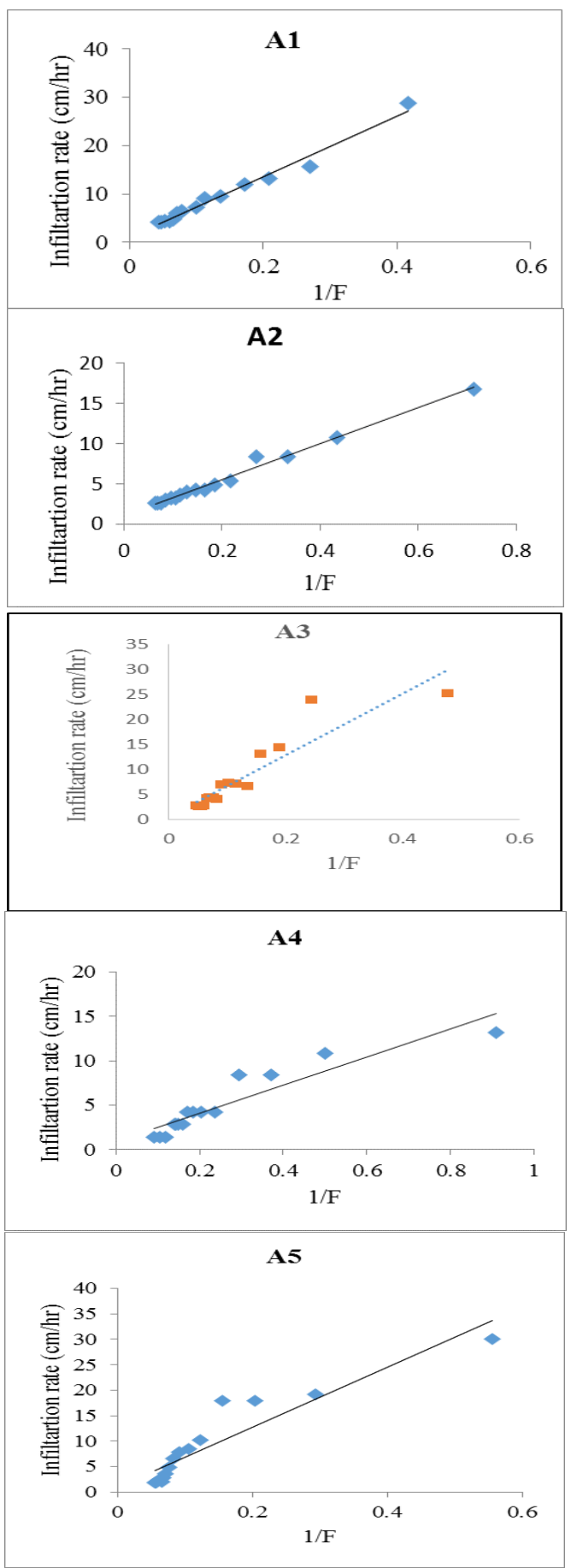




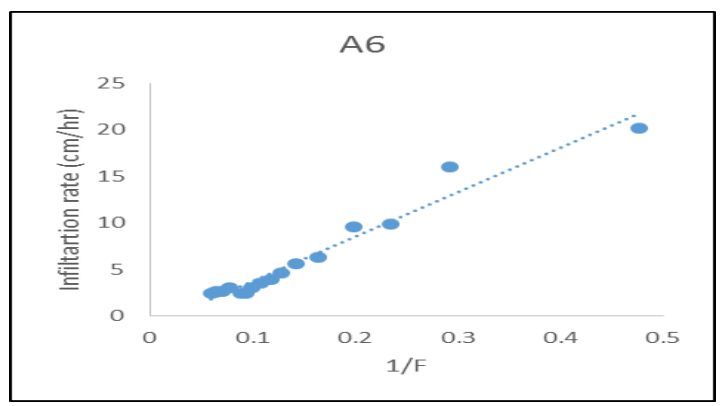

Fig.1. Curve fittings for estimation of saturate hydraulic conductivity for 6 different locations

\section{Descriptive Statistics Of Soil Physical Parameters}

The mean moisture content for the experimental site is found $7.47 \%$ with the maximum value of $11.3 \%$. The mean bulk density for the experimental site is found 1.8 $\mathrm{gm} / \mathrm{cm} 3$ with the maximum and minimum values are 1.69 and $2.10 \mathrm{gm} / \mathrm{cm}^{3}$. The mean basic infiltration rate for all the 6 infiltration tests carried out in a systematic square grid pattern was found to be $2.44 \mathrm{~cm} / \mathrm{h}$ with the maximum and minimum values of $4.2 \mathrm{~cm} / \mathrm{h}$ and $1.4 \mathrm{~cm} / \mathrm{h}$, respectively.

Table 1. Descriptive statistics of soil physical parameters

\begin{tabular}{|c|c|c|c|}
\multicolumn{2}{c}{ Table 1. Descriptive statistics of soil physical parameters } \\
\hline Parameters & $\begin{array}{c}\text { Moisture content } \\
(\%)\end{array}$ & $\begin{array}{c}\text { Bulk Density } \\
\left(\mathrm{g} / \mathrm{cm}^{3}\right)\end{array}$ & $\begin{array}{c}\text { Ks from Green } \\
\text { Ampt }(\mathrm{cm} / \mathrm{h})\end{array}$ \\
\hline Mean & 07.47 & 01.89 & 00.95 \\
\hline Standard Error & 01.71 & 00.07 & 00.07 \\
\hline Median & 07.88 & 01.87 & 01.02 \\
\hline $\begin{array}{c}\text { Standard } \\
\text { Deviation }\end{array}$ & 04.19 & 0.187 & 00.17 \\
\hline $\begin{array}{c}\text { Sample } \\
\text { Variance }\end{array}$ & 17.54 & 00.03 & 00.03 \\
\hline Range & 11.30 & 00.41 & 00.47 \\
\hline $\begin{array}{c}\text { Minimum } \\
\text { Maximum }\end{array}$ & 00.00 & 01.69 & 00.63 \\
\hline Sum & 11.30 & 02.10 & 01.11 \\
\hline Count & 44.84 & 11.35 & 05.70 \\
\hline
\end{tabular}




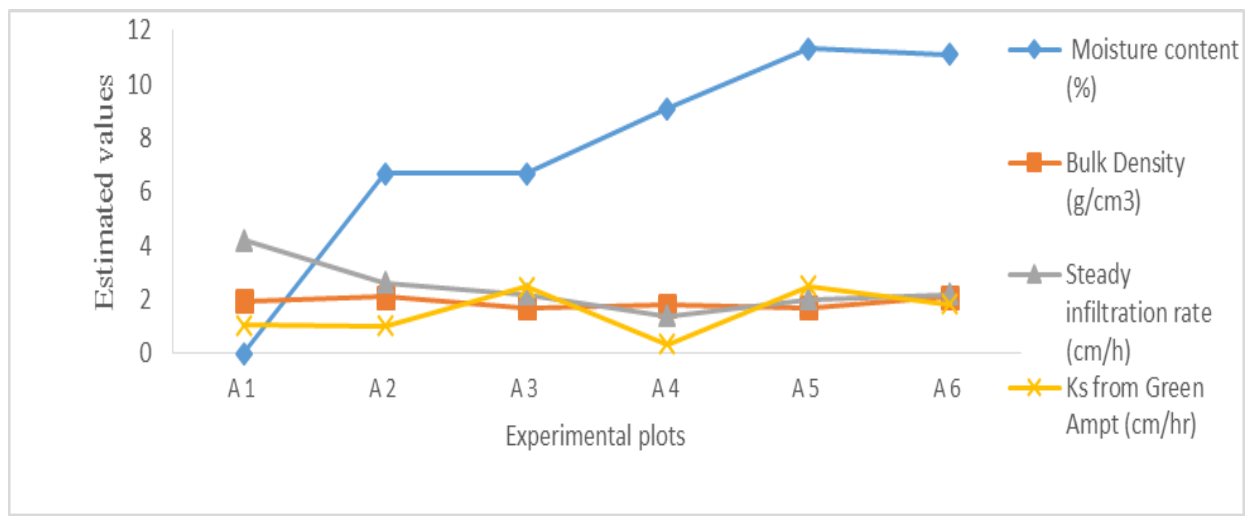

Fig. 2. Experimental plots Soil physical parameters

\section{CONCLUSION}

In this paper, we have tried to identify the spatial variability of infiltration characteristics and finding saturated hydraulic conductivity at 6 plots with $15 \mathrm{~m} \times 15 \mathrm{~m}$ at VFSTR campus, Vadlamudi, Guntur district, Andhra Pradesh, India. The study reveals that infiltration rates vary throughout the plots. It was observed that the plot A1, A2, A6 having more bulk density because of organic compounds in that area having comparatively less infiltration rate than A3, A4, A5 and point A1 having less moisture content with soil bulk density $1.95 \mathrm{~g} / \mathrm{cm}^{3}$ and having maximum infiltration rate $4.2 \mathrm{~cm} / \mathrm{h}$. The estimated average saturated hydraulic conductivity $\left(\mathrm{K}_{\mathrm{S}}\right)$ of the experimental plot is $0.95 \mathrm{~cm} / \mathrm{h}$. The knowledge of infiltration characteristics can be used to construct irrigation and drainage systems.

\section{REFERENCES}

[1] Bevin K. J, (2004). Robert E. Horton's perceptual model of infiltration processes. Hydro.Processes 18: 3447-3460.

[2] Das P, Islam A, Dutta S, Dubey A K and Sarkar R (2014). Estimation of runoff curve numbers using a physically-based approach of preferential flow modelling. In: Hydrology in a Changing World: Environmental and Human Dimensions: Proc. of the FRIEND-Water 2014; IAHS Publication: Wallingford, Germany, Vol. 363: 443-448.

[3] Fashi H. F., Gorji1 M and Shorafa M, (2016). Estimation of soil hydraulic parameters for different land-uses. Model. Earth Syst. Environ 2: 171-177.

[4] Green W. H. and Ampt G (1911). Studies of Soil Physics, Part 1. The flow of air and water through soils. Journal of Agricultural Science 4: 1-24.

[5] Hillel, D. (1998). Environmental Soil Physics. Academic Press, San Diego, California

[6] Islam A, Mailapalli D R and Behera A (2017). Evaluation of Saturated Hydraulic Conductivity Methods for Different Land Uses. Indian Journal of Ecology. Volume 44 (3): 456-466. 
[7] Islam A, Mailapalli D. R. and Behera A. (2019). Comparison of Saturated Hydraulic Conductivity Methods for Sandy Loam Soil with Different Land Uses. In: Rathinasamy M., Chandramouli S., Phanindra K., Mahesh U. (eds) Water Resources and Environmental Engineering I. Springer, Singapore. Water Resources and Env. Engineering: 99-117.

[8] Kostiakov A. N. (1932). On the dynamics of the coefficient of water-percolation in soils and on the necessity for studying it from a dynamic point of view for purposes of amelioration. Transactions Congress International Society for Soil Science, 6th, Moscow, Part A: 17-21.

[9] Kostiakov A. N. (1932). On the dynamics of the coefficients of water percolation in soils. In Sixth Commission, International Society of Soil Science, Part A; 15-21.

[10] Rawls W. J., Ahuja L. R., Brakensiek D. L., and Shirmohammadi A. (1993). Infiltration and soil water movement. In Handbook of Hydrology. McGraw-Hill, Inc.

[11] Rooij G. (2010). Comments on "Improving the numerical simulation of soil moisture-based Richards's equation for land models with a deep or shallow water table. Journal Hydrometeorology, 11:1044-1050.

[12] Sihag P., Tiwari N. K. and Subodh R 2017. Estimation and inter-comparison of infiltration models. Water Science 31: 34-43.

[13] Skaggs R. W. and Khaleel R (1982). Chapter 4: Infiltration. In Hydrology of Small Wathersheds. St Joseph, Mich.: ASAE.

\title{
PROCENA HIDRAULIČKE PROVODLJIVOSTI ZEMLJIŠTA NA VFSTR KAMPUSU UPOTREBOM METODE DRI
}

\author{
Aminul Islam*', K Ravi Chandra Charyulu' ${ }^{1}$, Rami Reddy ${ }^{1}$ \\ Department of Applied Engineering, Vignan's Foundation for Science, \\ Technology and Research, Vadlamudi, 522213, India.
}

Sažetak: Istraživanje hidraulične provodljivosti zemljišta najvažniji je parametar za protok tečnosti i transport molekula kroz profil zemljišta. Voda dospeva na površinu zemljišta u obliku padavina, navodnjavanjem i može prolaziti kroz profil zemljišta, i na kraju dospeva $\mathrm{u}$ veće dubine $\mathrm{i}$ formira različite forme podzemne vode. Procena hidrauličke provodljivosti zasićenog zemljišta (Ks) je hidraulička osobina zemljišta koja utiče na sposobnost prolaska kroz podzemnu sredinu i pomaže u razumievanju osobina prenosa i ravnoteže vode u zemljištima. Model Green-Ampt (G-A) je najprikladniji za infiltraciju na homogenim, u početku suvim i grubim zemljištima.

Studija je sprovedena za procenu procenta infiltracije kroz zemljište korišćenjem insitu metode Double Ring Infiltrometer (DRI) i određivanjem prostorne varijacije brzine infiltracije i procenom hidrauličke provodljivosti pomoću modela Green-Ampt (GA) za 6 oglednih površine od $15 \mathrm{~m}$ x15m, svaki kod mesta Vadlamudi, okrug Guntur, Andhra Pradesh (India).

Eksperiment obuhvata površine A1, A2, A6 koje imaju veću vrednost zapreminske težine zemljišta zbog sadržaja organskih jedinjenja u toj oblasti, i koja imaju relativno manji rang infiltracije od površine A3, A4, A5.

\footnotetext{
* Corresponding Author. E-mail addres. aminul.ubkv@gmail.com
} 
Površina A1 sa manjim sadržajem vlage i vrednosti zapreminske težine zemljišta od $1,95 \mathrm{~g} / \mathrm{cm}^{3}$ imaju maksimalnu brzinu infiltracije od $4,2 \mathrm{~cm} / \mathrm{h}$. Prosečno određena vrednost Ks sa eksperimentalnog polja je $0,95 \mathrm{~cm} / \mathrm{h}$.

Ključne reči: Hidraulička provodljivost, procenat infiltracije, padavine,

model Green-Ampt. (G-A), dvostruki kružni infiltrometar (DRI)

Prijavljen:

Submitted:

17.07.2019.

Ispravljen:

Revised:

01.09.2019.

Prihvaćen:

Accepted:

20.01.2020. 